Article

\title{
The Impact of Interest Rate, Exchange Rate and European Business Climate on Economic Growth in Romania: An ARDL Approach with Structural Breaks
}

\author{
Mariana Hatmanu $^{1, *}$, Cristina Cautisanu ${ }^{2}$ (D) and Mihaela Ifrim ${ }^{1}$ \\ 1 Faculty of Economics and Business Administration, Alexandru Ioan Cuza University of Iasi, \\ 700505 Iasi, Romania; mihaela.ifrim@uaic.ro \\ 2 CERNESIM Environmental Research Center, Alexandru Ioan Cuza University of Iasi, 700505 Iasi, Romania; \\ cristina.cautisanu@uaic.ro \\ * Correspondence: mariana.hatmanu@uaic.ro
}

Received: 5 February 2020; Accepted: 28 March 2020; Published: 1 April 2020

\begin{abstract}
The role of the interest and exchange rates in sustaining economic growth has been a highly researched subject. Therefore, this study examines the influence of the monetary policy interest rate, the real exchange rate and the business climate in the Euro area on the economic growth in Romania. For this purpose, we have applied a pre-test for structural breaks to identify the existence of structural breaks, followed by the traditional unit root tests and the unit root tests with structural breaks to verify the stationarity of the variables. The results of the Bound cointegration test led to the autoregressive distributed lag (ARDL) short-run model that measures the short-run impact of the interest rate, exchange rate and the business climate in the Euro area on the economic growth of Romania. Our findings show that in the short run, the economic growth is negatively influenced by the interest rate, and positively by the exchange rate. We also indicate that the business climate in the Euro area has mixed effects on the economic growth. Finally, considering the growing interdependence between the internal and external (European) business environment, the results are highly significant for handling the interest and exchange rates in sustaining economic growth.
\end{abstract}

Keywords: economic growth; unit root tests; multiple structural breaks; Bound cointegration test; econometric model

\section{Introduction}

The study of the influence of interest rate and exchange rate on the economic growth in Romania is highly important, especially in the light of joining the Euro area. Deepening the economic integration process involves, if not the adoption of the common monetary policy, the alignment of Romania's monetary policy with the policy of the Euro area. The convergence of Romanian monetary policy with the monetary policy in the Euro area is justified on three levels, as follows: a growing business cycle correlation, similar responses of central banks to relatively symmetrical external shocks and the stabilization policies of the interest rates. Due to different perspectives towards the economic influences of these instruments, our study aims, on the one hand, to (1) identify the effects of the monetary policy interest rate and of the exchange rate on the economic growth in Romania, and also, (2), to analyse the influence of the European business climate on the economic growth in Romania, taking into account the interdependence between the confidence in the economy and the interest rate and the exchange rate, respectively. Our study is built on four pillars, namely, the interdependence between the interest rate, the exchange rate, the economic growth and the business climate in the Euro area. This study belongs to the group of studies investigating the impact of interest rates and exchange 
rates on economic growth by relating domestic growth to the external business climate, measured by means of business climate indicators.

The main goal of the National Bank of Romania (NBR) is to ensure and maintain price stability and its main tasks are to design and implement the monetary policy and the exchange rate policy. The monetary policy interest rates influence the short-term money market levels of interest rates, which, in their turn, can stimulate investment, consumption or saving. In line with Keynesian argumentation, interest rate reduction may stimulate the aggregate demand in the short run, being at the same time an impulse to increase investments. Such a measure may have beneficial effects for immediate economic growth, but it discourages savings. The threat of inflation and the inability to sustain both high consumption and increased investments mean that, in the long run, we should expect distortions in the relative price system and a faulty resource allocation (as the Austrian business cycle theory shows). A low interest rate also leads to a decrease in foreign direct investment (FDI) attractiveness, resulting in lower capital flows and currency depreciation. Low interest rates could stimulate economic activity in the short term, but it could distort the relative prices and cause malinvestments. The appreciation of a currency will lead to cheaper imports and could cause lower inflation. It may lift the standard of living as people could afford buying more goods. The effects of an appreciation depend on the price elasticity of demand for imported and exported goods, the phase of the business cycle, if domestic economy is in an expansionary or a recessionary phase and on the economic context of the trading partners. In the short run, it is depreciation that could drive economic growth through cheaper exports (that is why so many developing countries prefer to depreciate their currency, even with the risk of inflation), but an appreciation, if it is the result of improved competitiveness, does not exclude economic growth. The alignment of Romania's interest rate with the interest rate of the Euro area, and the equilibrium between the monetary policy and exchange rate policy, provide clues for taking into consideration the European business climate in the decisions made on domestic policies. The economy trends in the Euro area are emphasized by the GDP evolution, while its changes can be predicted by consumer and business confidence indicators. The relationship between confidence and cyclical fluctuations of the economic activity has been debated since the 1920s. Barsky and Sims identified two distinct perspectives regarding the role of confidence in macroeconomics [1]. One perspective supports the effect of autonomous changes in the consumers' behaviour on the economic activity. Thus, the optimistic or pessimistic waves, labelled as "animal spirits", are considered major determinants of economic fluctuations, following A. Pigou and J.M. Keynes. The second perspective identifies fundamental information about the current and future state of the economy in measuring the indicators of consumers' behaviour. The confidence factors, reflected in the Business Confidence Indicator, provide important information about the business climate in the Euro area, being strongly linked to the economic growth.

To reach our goal, we set the following objectives: (i) To analyse the evolution of the economic growth rate in comparison with the monetary policy interest rate, the exchange rate and the business climate in the Euro area; (ii) to identify the structural breaks occurred in the evolution of the considered variables; (iii) to measure the impact of these variables on the economic growth in Romania.

The results of this study show that in Romania, the monetary policy interest rate, the real exchange rate and the European business climate have significant influences on the economic growth. The impact of these factors on the economic growth was measured using the ARDL model, corrected with the dummy variables attached to the structural breaks.

The paper has five sections. After the introductory section, Section 2 presents the general framework of the literature on the relationship between economic growth, interest rate, exchange rate and business climate, and describes the research hypotheses. Section 3 comprises the description of the data and used methodology. The results are presented in Section 4. The paper ends with discussions and conclusions in Section 5 . 


\section{Literature Review and Research Hypotheses}

In terms of the relationship between the interest rate and economic growth, such theories as those put forward by Barro and Sala-i-Martin [2] and Harvey [3] emphasize the impact of interest rate on the economic growth both in the short and long run. In the context of the short-run economic growth, the increase in interest rates make the population avoid getting bank loans or investing, these determining a lower economic activity and, implicitly, a lower level of economic growth.

The empirical tests of the relations between interest rate and economic growth have been mostly in favour of their negative relation. Authors such as Hossain [4], Low and Chan [5], Abdelkafi [6] and Ozer and Karagol [7] applied various methods specific to time series (Granger causalities, autoregressive models with distributed lag and error correction models) in order to study the influence of monetary policy instruments on economic growth. The study conducted by Hossain over a period of 62 years on the determinants of economic growth in Bangladesh indicated that inflation causes an increase in the interest rate and exchange rate volatility, the latter affecting economic performance [4]. The results of Low and Chan [5] from a study covering Malaysia are in concordance with the results reported by Hossain [4], where the inflation rate plays an important role and indirectly influences economic growth through its effects on the interest rate and exchange rate. Próchniak and Witkowski analysed the impact of the monetary policy interest rate on the economic growth in EU27 countries during 1993-2010, and in the EU15 between 1972 and 2010, obtaining mixed and unstable results [8]. Thus, for the years 1993-2004, they found a negative relationship between the interest rate and the economic growth, but for the years 2005-2010, the estimated coefficient on the interest rate was positive, questioning the effectiveness of manipulating the interest rate to stimulate the recovery of an economy in recession. Mallick and Sousa found that contractionary monetary policy (an increase in interest rate) has a strong and negative effect on the output of Brazil, Russia, India, China and South Africa [9]. Murgia [10] estimated the effects of the interest rate, along with other European central bank monetary policy instruments, on the industrial production in the Euro area, obtaining the result that industrial production responds to a monetary policy shock with a decline of over $0.5 \%$. Warman and Thirlwall found no favourable effects of interest rates on economic growth in Mexico between 1960 and 1990 [11].

Analysing the transmission mechanism of monetary policy for 10 transition economies during the years 1995-2002, Ganev et al. found that a positive interest rate shock reduced output in the short run in Slovakia, Hungary and Slovenia, raised it in Lithuania, Estonia, Czech Republic and Poland, but had mixed results for Latvia, Bulgaria and Romania [12]. At the same time, Ozer and Karagol showed that the relation between the monetary policy interest rate and economic growth is significant only in the short run [7].

Other economic theories show a bidirectional relationship between the interest rate and economic growth. On the one hand, economic growth can influence the interest rate [13-17] while, on the other hand, the interest rate may influence the economic growth [18-20]. Abdelkafi highlighted that there is a bidirectional relation between them, the monetary policies and the economic activity being interdependent [6]. Lee and Werner rejected the canonical theory of the influences that the interest rate may have on economic growth, obtaining for the United States, Germany, UK and Japan reversed Granger causalities and stating that economic growth is a cause factor for the interest rate [21]. Thus, they believe that the interest rates, both in a short and long run, follow the nominal GDP trend.

As far as the influence of the exchange rate on the economic growth, two main channels have been identified: international trade and investments.

The positive relation between international trade and economic growth can be found in the literature since that of Adam Smith. The works of the last decades have especially analysed the empirical evidence of the impact of trade on growth with mixed results according to the analytical instruments and used assumptions. The dogmatic approach, rooted in the economic logic, is found in the OECD report regarding the sources of economic growth. Therefore, international trade is not only linked to the benefits resulting from the exploitation of comparative advantages, but it also provides additional gains in terms of economic growth by means of scale economies, competition exposure 
and knowledge transmission [22]. Similarly, the study conducted by Frankel and Romer concluded that trade increases income by stimulating the accumulation of capital [19]. Irwin and Tervio, when analysing the relationship between international trade and economic growth throughout the 20th century, reached the same conclusion: Countries with a higher proportion of international trade in their GDP have higher incomes [23].

If international trade positively influences economic growth, exchange rate has a significant role in trade flows. A UNCTAD study of 2013 reports that exchange rate misalignments substantially affect international trade, being responsible for trade diversion, quantifiable at approximately one percent of the global trade [24]. The examination, in an IMF study, of historical evidence of the relationships between exchange rate, prices and volume of international trade for 60 economies reached the following result: Exchange rate movements tend to have strong effects on exports and imports. The study estimates that a depreciation by 10 percent of a domestic currency is associated, on average, with $1.5 \%$ of GDP rise in real net exports [25].

Investments are another important source for domestic and foreign economic growth. Investments can stimulate economic growth by diffusing knowledge, being an important source of know-how and human capital. The relationship between investments and growth is a bidirectional one. Iamsiraroj identified a virtuous cycle that "suggests that FDI contributes to economic growth and growth attracts FDI inflows, which in turn stimulates growth further" [26]. Foreign direct investments have an important contribution to economic growth by means of technology transfer, especially in economies with a significant absorption capacity [27].

As far as the relationship between exchange rate and economic growth is concerned, Sipoș and Boleanț proved the existence of a unidirectional relation between them, the exchange rate having a decisive impact on economic growth in Romania [28]. At the opposite end, Anaripour indicated that in the case of specific countries in South America and Asia, there is a reversed causality between the two variables, the economic growth having a significant effect on the exchange rate [29]. Rodrik showed that a high real exchange rate stimulates economic growth [30]. On the same line, Razmi et al. identified a positive relation between the real exchange rate undervaluation and economic growth, especially in the case of emerging economies [31]. Ribeiro et al. claimed that the real exchange rate affects growth indirectly through its impacts on functional income distribution and technological innovation [32].

Using a VAR model, Wesseh and Lin found that the depreciation of the Liberian dollar causes a decrease in the real GDP, while its appreciation has no impact on real GDP in Liberia [33]. Habib et al. used data for 150 countries for the period 1970-2010 and found that a real appreciation significantly reduces the annual real GDP growth [34]. Eichengreen asserted that the maintenance of the real exchange rate at a competitive level and the avoidance of excessive volatility are important for economic growth [35]. On the other hand, Ihnatov and Capraru claimed that, even if the exchange rate stability is important for ensuring economic growth, it loses its function when the obtained stability involves important interventions of the monetary authorities [36].

An important role in attracting investments is played by the business climate in the destination country. Thus, price stability, exchange rate predictability and economic stability of a country determine the increase in interest and confidence of investors to start up a business in a foreign country. The changes in the exchange rate generate responses in the FDI inflows. Oliveira found that the greater the volatility of the exchange rate, the lower the investments [37]. Sharifi-Renani and Mirfatah reached the same conclusion, the exchange rate volatility, by increasing risk and uncertainty, reduces FDI incentives [38]. Froot and Stein examined the relationship between exchange rate and investments and showed that the changes of exchange rate determine changes in wealth, which in turn generates modifications in the demand of direct investments [39]. When analysing the FDI determinants in the United States, Grosse and Trevino concluded that an appreciation of the exchange rate and an increase in the purchasing power for American assets lead to an increase in foreign investments in that country [40]. For US economy, Klein and Rosengren's study also stated that "a depreciation 
(appreciation) of the bilateral real exchange rate is correlated with an increase (decrease) in the inflow of FDI" [41]. Takagi and Shi found that Japanese FDI in the Asian economies declined with the yen depreciation against the currencies of the host countries [42].

In a less conventional way, but no less relevant, economic growth can be estimated based on the confidence indicators. These confidence indicators could be estimated at the national or regional level. For our study we referred to the Euro area confidence indicator. The consumers' confidence and the climate of confidence where different producers from different industries perform their activity, are useful indicators which allow to keep track of the economic evolution in the Euro area [43]. The use of confidence indicators has its origin in an approach started in the 1940s at the University of Michigan. Katona's Index of Consumer Sentiment (1951) lays the foundations of using consumer behaviour in the estimation of the dynamics of consumption expenditures in the United States. At the European level, the confidence indicators target both the consumers and the producers (grouped by activity sectors: industry, constructions, retail trade and services). Analysis of the Euro area's economic activity is facilitated by the use of composite indicators, which, through their monthly frequency, allow for a better monitoring of the economic activity [44]. Strigel showed there is a very good relationship between economic climate indicators and economic performance, these providing early indices on the direction of the cyclical evolution of the economy [45]. Furthermore, the climate indicators reflect quite quickly the changes in financial variables (the interest rate, the exchange rate) that affect the "sentiment" of consumers and producers [45]. Thus, the confidence/sentiment indicators can function as "early barometers" in the evolution of an economy [46].

Measuring the business sentiment provides valuable information for the evaluation of the economic situation and for performing forecasts as shown by the OECD study performed by Santero and Westerlund [47]. They examined the relationship between consumer and business confidence indicators and the GDP for 11 OECD countries for the period 1979-1995. The relevance of the confidence indicators also comes, according to the authors, from the fact that the data obtained in qualitative surveys (sentiment data) are more relevant because the trend and seasonality issues are avoided, being at the same time isolated from the distortions that may characterize "real" statistics. Data lags and data revisions lengthen the measuring processes, while the confidence indicators track the major cyclical movements of industrial production. If Santero and Westerlund identified a limit in the use of confidence indicators for the performance of short-run forecasts, due to lack of a sequential behaviour consistent with the movements in the production activity, Mourougane and Roma considered that these can be useful in forecasting the growth rates of GDP [48]. Using a Dynamic Factor Model (DFM), Hansson and Jansson showed that, for Sweden, the data from the business tendency surveys are useful for forecasting the short-run GDP evolution [49].

Demirel and Artan studied the effects of confidence indicators on the macroeconomic variables in 13 European Union countries for the period 2000-2014 and showed that confidence influences the production level, the consumption level, inflation rate and unemployment [50]. Furthermore, trust is associated with better economic performances, as stated by Knack and Keefer [51], while Gennaioli found that expectations have a major role on economic growth [52]. In the study of Das and Das [53] the Business Confidence Indicator (BCI) is a significant variable for economic growth in Germany, Spain and Japan. Alves [54] found that fluctuation in the Business Confidence Indicator (BCI) have a significant impact on Portugal's industrial production. Zanin analysed the relationship between the changes in the Economic Sentiment Indicator and the GDP increase for six countries, with mixed results. The best relations were obtained for France and Italy, included in the group of the most developed economies in the Euro area [55]. Using an autoregressive distributed lag (ARDL) model for South Africa, De Jongh and Mncayi found that an increase of one percent in business confidence may lead to an economic growth of $0.23 \%$ [56].

The traditional perspective to measuring economic activity is based on information provided by the GDP indicator. Beyond its measuring limits, GDP provides only quarterly or annual information. Moreover, the gap of several weeks between the data publication and the period they refer leads to 
belated knowledge about the evolution of a country's economy. Although important, it would be more helpful to use information with higher frequencies, such as monthly data. Therefore, we will use the Industrial Production Index (IPI) to measure economic growth.

The analysis of the relationship between the interest rate, the exchange rate and the economic growth in Romania is the main goal of our study, to which we will also add the influence of the business climate in the Euro area.

Using the main lines of research identified in the literature review, we formulated the following research hypotheses:

Hypothesis 1. The interest rate influences economic growth in Romania.

Although the Central Bank of Romania does not aim to stimulate economic growth, the establishment of market policy interest rate for open market operations provides a significant sign of access to consumption and investment loans. This way, the interest rate calibrates both supply and demand in economy, being a determining factor of growth.

Hypothesis 2. The exchange rate influences economic growth in Romania.

Managed float regime allows the Central Bank of Romania to respond in case of external shocks, at the same time, the exchange rate influencing the economic activity through net exports and wealth and balance sheet effects. Stimulation of exports and industrial production by means of monetary depreciation should be put in balance with inflation, indebtedness and capital flights.

Hypothesis 3. The business climate in the Euro area influences economic growth in Romania.

Business climate measures the trust of producers in positive evolution of economy. Growth of demand and economic activity in the Euro area are incentives for industrial production in Romania, being heavily dependent on the European market.

\section{Data and Empirical Methodology}

\subsection{Data}

This study analyses the data regarding the industrial production index, the monetary policy interest rate, the real exchange rate and the Euro area Business Climate Indicator for the period January 2003-December 2019. In order to eliminate the influence of seasonal variations, we took into consideration the seasonally adjusted variant of the industrial production index and the Euro area Business Climate Indicator. The data were collected from the websites Eurostat and the National Bank of Romania.

The industrial production index (IPI) is calculated as a Laspeyres index and measures the changes in the production volume at regular intervals, usually every month [57]. IPI is one of the most relevant indicators for measuring real economy, and in this study it is used as a measure of economic growth.

In Romania, for the analysed period, which also comprises the economic/financial crisis of 2007 that extended until 2010-2012, some branches of the national economy, such as agriculture and construction, went through an accentuated decline. Industry continued to be the main pillar of economic growth and, even if during the privatization process it had suffered a lot, it maintained its major contribution to the GDP, comprised between its lowest level, equal to 23.1\% registered in the years 2015 and 2016 [58], and its highest level of $26.4 \%$ in 2010 [59].

Taking into account that industrial production holds the dominant weight in the total economic activity, when highlighting the changes in the industrial production volume, the industrial production index provides a general overview of the dynamics of a country's economy. The monthly data of the industrial production index provides businesses with information on the production changes, and 
indirectly, on the changes of domestic economic growth. At the same time, political decision-makers can use the data of the industrial production index as signals in handling monetary or fiscal policy instruments. The set of instruments used by the National Bank of Romania (NBR) to implement its monetary policy count open market operations, standing facilities and reserve requirements. The monetary policy interest rate is the interest rate used for the main open market operations of the NBR. Currently, these are one-week repo operations. Monetary policy rate replaces the NBR's reference interest rate starting with the 1st of September 2011 [60].

The exchange rate represents the price based on which a currency is changed with another one, namely, the ratio between a domestic currency and a foreign one. The real exchange rate is of great importance for both decision makers and economic agents because it reflects the competitiveness of prices and costs [61]. The real exchange rate is determined by adjusting the nominal exchange rate to the inflation rates between the two countries, according to the relation

$$
\text { R_EXCH }=\text { N_EXCH } \frac{\text { HICP_i }}{\text { HICP_RO }}
$$

where R_EXCH is the real exchange rate, $\mathrm{N} \_$EXCH is the nominal exchange rate and HICP_RO and HICP_i is the consumer price indices in the country, respectively, out of the country.

For the calculation of the RON/Euro real exchange rate, the authors used the consumer price index for Romania and, respectively, the average consumer price index for the Euro area. The interest rate and the exchange rate do not have seasonal variations and their seasonally adjustment was not needed.

The Euro area Business Climate Indicator (BCI) is a composed indicator of the manufacturing industry in the Euro area and it is obtained by processing the data collected through business and consumer surveys. These surveys are performed on a monthly basis by the Institute of Statistics of the member states or of the states in the process of adherence to the European Union and, respectively, of the member states of the Organisation for Economic Cooperation and Development (OECD). The business and consumer surveys are performed in the following sectors of economic activity: manufacturing industry, construction, consumption, retail trade and services. An important feature of the business and consumer surveys is that almost all the questions are qualitative. The goal of business and consumer surveys is to calculate confidence indicators in order to reflect the evolution of the macroeconomic indicators, being the key complement of official statistical data, which in general are quantitative. $\mathrm{BCI}$ is computed based on the answers provided by the representatives of the biggest companies in the manufacturing industry in the Euro area to five questions regarding production trends in recent months, order books, export order books, stocks and production expectations [43]. The method used to determine BCI has at its basis the fundamental principles of the Principal Component Analysis (PCA) and it is represented by the main factors extracted from the five components of the industry survey. Calculated in this manner, it is believed that BCI must increase alongside the entire industrial activity in the Euro area and the BCI importance is supported by the fact that more than a half of the GDP variations are represented by the fluctuations of the industrial activities [44]. For that matter, the European Commission considers the economic climate as being of utmost importance in the evolution of an economic cycle while the confidence indicators in an industry have the advantage that they offer a lot more and quicker information about the GDP evolution than the official statistical data [62].

In this paper, the authors used the following symbols for the variables: the industrial production index-IPI; monetary policy interest rate-INT; the real exchange rate- $\mathrm{R} \_\mathrm{EXCH}$; and the Euro area Business Climate Indicator-BCI.

\subsection{Empirical Methodology}

In order to empirically analyse the long-run relationships and the short-run dynamic interactions among the variables, we applied the autoregressive distributed lag (ARDL) cointegration technique. The research approach comprises the following steps: (1) testing for the unit root without and with 
structural breaks for the selected variables; (2) identifying the types of relationships among the variables; and (3) modelling the relationships among variables.

\subsubsection{Testing for Unit Roots and Structural Breaks}

Since the ARDL approach cannot be applied when some variables are integrated with a two or higher order than two, it is important to perform unit root tests on all regressors [63]. There are several unit root and stationarity tests, such as Augmented Dickey-Fuller (ADF) [64], Phillips-Perron (PP) [65], Kwiatkowsky-Phillips-Schmidt-Shin (KPSS) [66] or Dickey-Fuller Generalized Least Squares (DF-GLS) [67]. However, these tests do not account for the potential structural breaks in the time series and could provide spurious results when the data are trend stationary with a structural break. The unit roots tests with structural breaks evolved from Perron [68] (considering one known structural change) to Zivot and Andrew [69] (considering one unknown break) and Lumsdaine and Papell [70] (considering two unknown breaks). Lee and Strazicich point out that the main drawback of the ZA and LP tests is that they assume breaks only under the alternative hypothesis [71]. Carrion-I-Silvestre et al. [72] propose robust versions for the tests originally developed by $\mathrm{Ng}$ and Perron [73], which allow for multiple structural breaks under both the null and the alternative hypotheses. The previous authors suggest implementing a pretesting procedure to assess whether a series has structural change in level and / or slope [74].

The Perron and Yabu [75] procedure checks for the presence of structural change, without prior knowledge of the series' order of integration. If a structural change is found, the robust unit root tests of Carrion-I-Silvestre et al. [72] are employed. If no breaks occur, unit root tests, such as the Augmented Dickey-Fuller and the Phillips-Perron can be used.

The Perron and Yabu procedure [75] considered three types of structural change: (i) Model I-structural change in the intercept; (ii) Model II-structural change in the slope; and (iii) Model III-structural change in the intercept and in the slope. The Perron and Yabu statistic test, called Exp-WFS, is based on a quasi-feasible Generalized Least Squares approach, using an autoregression for the noise component with a truncation to 1 when the sum of the autoregressive coefficients is in the neighbourhood of 1, along with a bias correction. According to Oscar Bajo-Rubio [76], for given break dates, Perron and Yabu [75] propose an F-test for the null hypothesis of no structural change in the deterministic components using the Exp function developed by Andrews and Ploberger [77].

The second step of the stationarity analysis consists of applying the Carrion-I-Silvestre et al. [72] set of robust tests to the series that feature a break in the trend function. Carrion-I-Silvestre et al. generated five different test statistics to check for the null hypothesis of a unit root under multiple structural breaks, which are the Elliot et al. [67] feasible point optimal test $\left(\mathrm{P}_{\mathrm{T}} \mathrm{GLS}\right)$ and its modified version $\left(\mathrm{MP}_{\mathrm{T}}{ }^{\mathrm{GLS}}\right)$, the Phillips [78] modified test $\left(\mathrm{MZ}_{\alpha}{ }^{\mathrm{GLS}}\right)$, the modified Sargan and Bhargava [79] test $\left(\mathrm{MSB}^{\mathrm{GLS}}\right)$ and the modified Phillips and Perron [65] test (MZt $\left.{ }^{\mathrm{GLS}}\right)$. The superscript GLS indicates that all the series are GLS detrended [74]. These tests are applied on the following models: (i) Model 1-for the constant case, without structural breaks; (ii) Model 2-for the linear time trend case, without structural breaks; (iii) Model 3-for the linear time trend with multiple structural breaks, which affects both the level and the slope of the time [80]. For all tests, the null hypothesis is rejected if the test statistic is smaller than the relevant critical value, suggesting the absence of a unit root in the series.

\subsubsection{The ARDL Bound Cointegration Test}

Even if the Autoregressive Distributed Lag (ARDL) models have been used in econometric modelling for decades, they have only gained popularity in recent years when they were used in the methods analysing cointegration relationships. In this regard, important contributions were made by Pesaran and Shin [81] and Pesaran, Shin and Smith [82]. Unlike other existing methods in the literature, such as Engle-Granger [83] and Johansen-Juselius [84], the ARDL cointegration method has the advantage to verify the existence of long-term relationships between variables that have different orders of integration, while the results of the analysis are robust for an incorrect specification of the 
order of integration. Other advantages of the ARDL cointegration technique mention the following aspects: Different restrictions can be applied in terms of the optimum number of lags of the variables under consideration [85]; it is based on a single equation, which estimates simultaneously both the short-run and the long-run relationships, which makes it easy to implement and interpret [86-89]. The ARDL Bound test model, used in this study is expressed as follows $[90,91]$ :

$$
\Delta Y_{t}=\sum_{i=1}^{p-1} \beta_{i} \Delta Y_{t-i}+\sum_{j=1}^{k} \sum_{l_{j}=0}^{q_{j}-1} \delta_{j, l_{j}} \Delta X_{j, t-l_{j}}+\theta Y_{t-1}+\sum_{j=1}^{k} \phi_{j} X_{j, t-1}+\lambda z_{t}+u_{t}
$$

where $Y_{t}$ is the dependent variable from the ARDL model, IPI in this study; $X_{j, t}, j=\overline{1, k}$ is the independent variables, INT, R_EXCH and BCI in this study; $k$ - the number of independent variables; $z_{t}$ is an $\mathrm{s} \times 1$ vector of deterministic variables such as the intercept term, dummy variables or time trends; $u_{t}$-the error term, $\beta_{i}$ and $\delta_{j, l_{j}}$ are the coefficients of the terms that indicate the short-run relationships; $\theta$ and $\phi_{j}$ are the coefficients of the terms that indicate the long-run relationships; $p$ and $q_{j}$ represent optimal lags for the variables $Y_{t}$ and $X_{j, t}$ identified based on information criteria; and $\lambda$ represents the coefficient attached to a term of the vector $z_{t}$.

The bounds test consists of testing the null hypothesis of no cointegration or long-run relationship between the considered variables using Fisher statistics. The null hypothesis is formulated regarding the coefficients from Equation (2) as follows: $H_{0}: \theta=0, \phi_{j}=0, \forall j=\overline{1, k}$. The asymptotic distribution of the test statistic is non-standard and Pesaran et al. [81] calculated the critical values for F-statistics. These critical values are obtained for different circumstances and define an interval for which the lower bound is determined based on the hypothesis that all variables are $\mathrm{I}(0)$, while the upper bound is calculated based on the hypothesis that all variables are I(1). The critical values of Pesaran et al. [82] are only useful and efficient for large sample sizes. Kripfganz and Schneider [92] extended the work of [82], determining with stochastic simulations the critical values that cover a full range of possible sample sizes and lag orders, allowing any number of variables in the long-run-level relationship.

According to the decision rule, if the calculated value of the F statistic is higher than the upper bound, the variables are cointegrated, and if it is inferior to the lower bound, then all variables are $\mathrm{I}(0)$, which means no long-run relationships can exist-in other words, the cointegration test is inconclusive.

The testing is completed by the verification of the significance of coefficient $\theta$ corresponding to the term $Y_{t-1}$, using the $t$ test. As in the case of F-statistics, the asymptotic distribution of the $t$ test statistics is non-standard, and the critical values of the t-statistics are provided by Pesaran et al. [82]. The absolute values of the t-statistics are compared against the corresponding critical values and the decision rule is similar to the one presented above for the Fisher test.

\subsubsection{Modelling the Relationships between the Variables}

According to the cointegration test results, for the modelling of the relationships between variables, different types of models are applied. If between the variables under consideration there are long-run relationships, an error correction model (ECM) is applied. At the opposite end, if there are no long-run relationships between variables, a short-run ARDL model is applied [81]. To validate the previously estimated model, the short-run ARDL or ECM, it is necessary to verify the hypotheses for the model coefficients and residual component.

The stability of coefficients is verified, according to the authors Brown et al. [93] and Pesaran and Pesaran [94], through the graphical representation of the cumulative sum of recursive residuals (CUSUM) and, respectively, the cumulative sum of square recursive residuals (CUSUM of Squares). The coefficients are stable if, within the two representations, the variance of residuals fits within the interval that indicates the variation limits for a significance level at $5 \%$. In order to verify if the model should be linear, it can be formally tested using Ramsey's RESET test [95], which is a general test for 
misspecification of functional form. If the value of the test statistic is greater than the $\chi^{2}$ critical value, the null hypothesis of the correctness of the functional form is rejected [96].

For validation of the model, it is also necessary to check the hypotheses formulated on the residual component using tests such as Jarque-Bera for the normality hypothesis; the Breusch-Godfrey Serial Correlation LM test for no serial correlation; as well as the Breusch-Pagan-Godfrey and ARCH tests for homoscedasticity.

The model robustness can be verified by comparing the results obtained through the ARDL approach with those indicated by the causality analysis, performed through the Granger causality test or the Toda-Yamamoto approach. The significance tests of the short-run or long-run coefficients and the Granger causality tests can identify causality relationships between variables in at least one direction $[97,98]$.

\section{Results}

4.1. A Comparative Analysis of Economic Growth vs. The Interest Rate, the Exchange Rate and the European Business Climate Evolution

In this section, we analyse the evolution of economic growth, measured by the industrial production index, in comparison with the evolution of the monetary policy interest rate, the real exchange rate and the Euro area Business Climate Indicator. The comparison of these evolutions focuses on the identification of the correlations between the industrial production index and the influence factors under consideration.

The comparative analysis of the industrial production index and the monetary policy interest rate evolution in Romania between January 2003 and December 2019, is shown in Figure 1. It can be observed that the two indices have a different evolution during January 2003 and March 2018, ascending in the case of the industrial production index and descending in the case of the monetary policy interest rate.

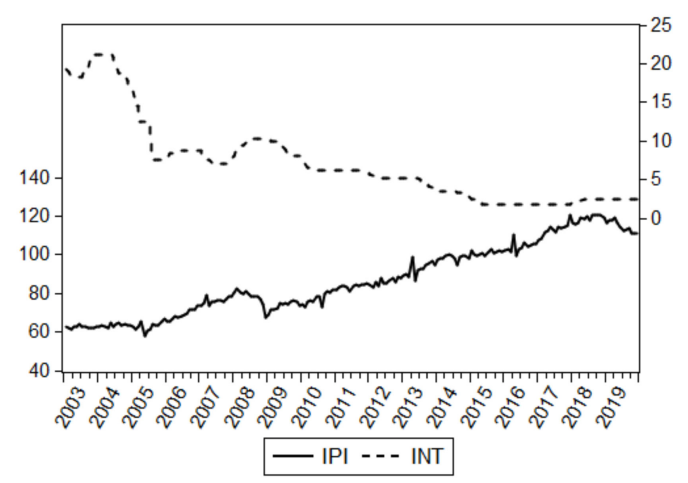

Figure 1. The evolution of the industrial production index and of the monetary policy interest rate in Romania.

Monetary policy interest rates have decreased significantly since 2003, when they reached $20 \%$, to values below $2 \%$ in 2015. In the context of Romania's adherence to the Euro area, the decrease in the monetary policy interest rate, as a result of the efforts to align the interest rate in Romania with the monetary policy in the Euro area, had a positive effect on industrial production. It can also be observed that the level of the interest rate during the period 2014-2019 is almost constant, with small decreases during the period 2015-2017, confirming the trend toward meeting a real sustainable convergence. Based on the graphical analysis, a negative relation between the two variables is observed.

In terms of comparative analysis of the evolution of the industrial production index and the real exchange rate in Romania (Figure 2), it can be seen that for a great part of the analysed period both indices have tendencies of slight increase. The outbreak of the economic crisis determined the beginning of the real exchange rate growth tendency in Romania. The inflationist pressures and 
the obvious break between savings, consumption and investments (see the Austrian theory of the economic cycle) imposed the increase in the interest rate. This way, the monetary policy in Romania followed the evolution of the Euro area, having as a goal the slight increase of the real exchange rate in order to reach a level close to the nominal convergence criterion for the fluctuation interval established according to the European Mechanism of Exchange Rates. In 2008 and 2009, more severe depreciations of the nominal RON/EUR exchange rate occurred due to tensions on the international markets, increasing mistrust of foreign investors, risk aversion and lower volume of liquidities [99]. After 2010, the industrial production and the real exchange rate have had similar trends, indicating a positive relationship between them.

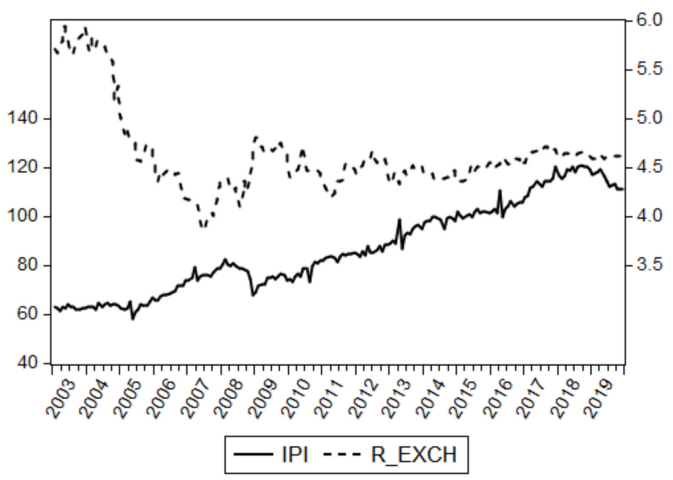

Figure 2. The evolution of the industrial production index and of the real exchange rate in Romania.

The comparative analysis between the industrial production index evolution in Romania and the Euro area Business Climate Indicator (Figure 3) shows that the two indices have a similar trend: During the period January 2003-December 2007, there was an increasing trend in the values for the two indices; at the beginning of the year 2008 there was a significant decreasing trend for both indices, these returning at approximately equal values within a 3-month interval; during the period January 2011-March 2018, there was a tendency of a slight increase in the values of both indices, with weak fluctuations; and during the period April 2018-December 2019, both indices had a slight decreasing tendency.

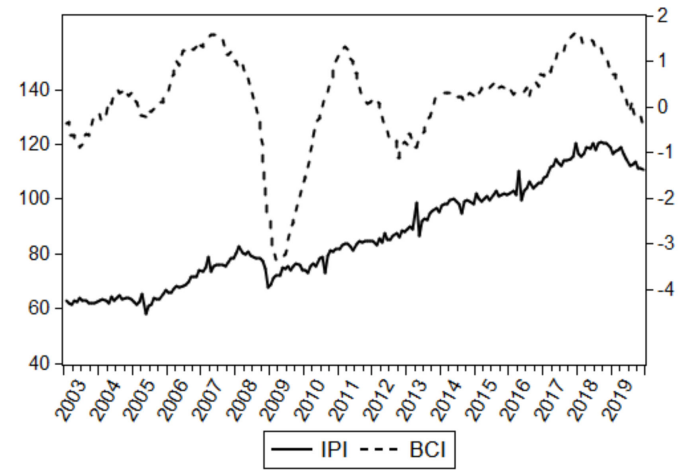

Figure 3. The evolution of the industrial production index in Romania and of the Euro area Business Climate Indicator.

The significant decreases in the values of the two indices, signalled at the beginning of 2008, are due to the effects of the global economic crisis at the end of 2007. So, economic activities in all economic sectors in Romania were negatively affected, especially the industrial sector that contributes the most to the GDP formation of Romania. The price instability in the industrial sector determined a decrease in investors' confidence in the Romanian market and, implicitly, their withdrawal, which created effects such as the contraction of industrial production and an increase in the unemployment rate. As far as the 
Euro Area Business Climate Indicator are concerned, they had a decrease of approximately $4 \%$ against the normal values. The effects of the economy manifested more intensely in Europe, while confidence in the economy decreased significantly. Within a 3-year interval, the negative effects of the crisis decreased, and the Euro area Business Climate Indicator reached values similar to the pre-crisis period.

\subsection{Testing for Unit Roots and Structural Breaks of the Variables Considered}

The first step of the approach of most modelling analyses of time series is to verify the stationarity of the variables analysed. The preliminary graphical analysis indicated some structural breaks, explained by the events that occurred in the analysed period, such as the economic and financial crisis of 2008. Furthermore, IPI, INT and R_EXCH present a linear trend, while BCI does not. In this regard, for the first three mentioned variables, the pre-test developed by Perron and Yabu [75] was performed in order to assess whether a structural break is present in the deterministic components.

The results of Perron and Yabu's test are presented in Table 1. According to the obtained results, the null hypothesis of an absence of a structural break in the intercept and slope is rejected at the $1 \%$ level of statistical significance for all three considered variables. The last column of the table includes the identified structural breaks.

Table 1. Results of the Perron and Yabu test.

\begin{tabular}{ccc}
\hline Variables & Test Statistic & Break \\
\hline IPI & $6.319^{* * *}$ & $2008 \mathrm{M} 10$ \\
INT & $95.702^{* * *}$ & $2005 \mathrm{M} 06$ \\
R_EXCH & $49.134^{* * *}$ & $2007 \mathrm{M} 10$ \\
\hline \multicolumn{2}{c}{ Note: ${ }^{* * *}$ denotes significance at the $1 \%$ level. }
\end{tabular}

Afterwards, we analysed the order of integration of the variables IPI, INT and R_EXCH, taking into consideration the presence of structural breaks. In this respect, the quasi-GLS approach of Carrion et al. [72] was applied, including the following set of unit root tests: $\mathrm{P}_{\mathrm{T}} \mathrm{GLS}, \mathrm{MP}_{\mathrm{T}}{ }^{\mathrm{GLS}}, \mathrm{MZ}_{\alpha}{ }^{\mathrm{GLS}}, \mathrm{MSB}^{\mathrm{GLS}}$ and $M Z_{t}{ }^{G L S}$. These tests were performed for each of the variables in levels and in 1st difference. The results are summarized in Table 2.

Table 2. Results of the Carrion et al. unit root tests.

\begin{tabular}{ccccccc}
\hline Variables & $\mathbf{P}_{\mathbf{T}}{ }^{\mathbf{G L S}}$ & $\mathbf{M P}_{\mathbf{T}}{ }^{\mathbf{G L S}}$ & $\mathbf{M Z}_{\boldsymbol{\alpha}}{ }^{\text {GLS }}$ & $\mathbf{M S B}^{\mathrm{GLS}}$ & $\mathbf{M Z}_{\mathbf{t}} \mathbf{G L S}^{2}$ & Breaks \\
\hline Levels $^{a}$ & \multicolumn{7}{c}{} & & \\
\hline IPI & 19.300 & 18.531 & -10.415 & 0.208 & -2.171 & 2013M03, 2013M05, 2016M04 \\
INT & 7.437 & 7.377 & -18.582 & 0.161 & -2.994 & 2004M05, 2005M03, 2005M07 \\
R_EXCH & 8.970 & 8.504 & -23.187 & 0.146 & -3.404 & 2004M10, 2004M12, 2008M08 \\
\hline 1st difference ${ }^{b}$ & & & & & - \\
\hline IPI & $1.073^{* *}$ & $1.072^{* *}$ & $-85.512^{* *}$ & $0.076^{* *}$ & $-6.537^{* *}$ & - \\
INT & $4.095^{* *}$ & $4.132^{* *}$ & $-22.061^{* *}$ & $0.150^{* *}$ & $-3.320^{* *}$ & - \\
R_EXCH & $1.378^{* *}$ & $1.387^{* *}$ & $-65.888^{* *}$ & $0.087^{* *}$ & $-5.738^{* *}$ & \\
\hline
\end{tabular}

Notes: ${ }^{* *}$ denotes significance at the $5 \%$ level. ${ }^{\text {a }}$ A model with structural breaks that affect both the level and the slope of the time trend was applied. ${ }^{b}$ A model with a trend, without structural breaks was estimated. The lag length for all the tests is selected via the MAIC criterion suggested by $\mathrm{Ng}$ and Perron [72].

For all tests, the null hypothesis is rejected if the test statistic is smaller than the relevant critical value. As it can be seen from the results above for IPI, INT and R_EXCH in levels, the null hypothesis is not rejected at the $5 \%$ level of significance. Table 2 also shows for each considered variable a maximum of three structural breaks that occurred in their evolution during the period January 2003-December 2019. For the variables in 1st difference, the unit root tests indicated the absence of a unit root, meaning that the considered variables have a maximum of one order of integration in the presence of structural breaks. 
Regarding BCI, the results of the Augmented Dickey-Fuller (ADF) and Phillip-Perron (PP) unit root tests, presented in Table 3, revealed that it is stationary at level.

Table 3. Results of the Augmented Dickey-Fuller (ADF) and the Phillip-Perron (PP) unit root tests.

\begin{tabular}{ccccccc}
\hline \multirow{2}{*}{ Variable } & \multicolumn{3}{c}{ ADF $^{\text {a }}$} & \multicolumn{4}{c}{ PP $^{\text {a }}$} \\
\cline { 2 - 6 } & $\begin{array}{c}t \text {-Test } \\
\text { (Level) }\end{array}$ & $\begin{array}{c}t \text {-Test } \\
\text { (1st Difference) }\end{array}$ & $\begin{array}{c}\text { Order of } \\
\text { Integration }\end{array}$ & $\begin{array}{c}t \text {-Test } \\
\text { (Level) }\end{array}$ & $\begin{array}{c}t \text {-Test } \\
\text { (1st Difference) }\end{array}$ & $\begin{array}{c}\text { Order of } \\
\text { Integration }\end{array}$ \\
\hline BCI & $\begin{array}{c}-4.577 \\
* * *\end{array}$ & - & $\mathrm{I}(0)$ & $-2.568^{* *}$ & - & $\mathrm{I}(0)$ \\
\hline
\end{tabular}

Notes: ${ }^{a}$ Model with intercept and trend. ${ }^{* * *}$ and ${ }^{* *}$ denote statistical significance at the $1 \%$ and $5 \%$ level, respectively.

Overall, the unit root tests indicate that the variables are integrated in the mixed order, but none are integrated for order two. These results determined a favourable context to the application of an ARDL Bounds test for cointegration.

\subsection{The ARDL Bound Cointegration Test}

In order to estimate the ARDL model, we performed a VAR model to identify the optimal number of lags between variables. Based on the results of the information criteria FPE, AIC, SC and HQ, we selected a number of five lags.

The validation of the ARDL model based on which the Bound test is applied implies the verification of coefficient stability and of hypotheses concerning the error variables. The representation of the CUSUM of Squares indicates the instability of coefficients for the ARDL model. For the model correction, dummy variables, as exogenous elements, were introduced, which were defined in relation to the structural breaks that determine the coefficients instability: a step dummy variable for the structural break identified in IPI (2008M10) by the Perron and Yabu test and some impulse dummies for the structural breaks identified in IPI (2013M03, 2013M05 and 2016M04) by the Carrion et al. tests [100].

The results of the ARDL Bounds test, regarding the existence of long-run relationships between IPI and the independent analysed variables, are presented in Table 4 . In order to obtain more precise results for this test and because we have a small sample, we considered both the set of critical values, as proposed by Pesaran et al. [82] and Kripfganz and Schneider [92].

Table 4. Results of ARDL Bounds Test.

\begin{tabular}{|c|c|c|c|c|c|}
\hline \multirow{3}{*}{ Test Statistic } & \multirow{3}{*}{ Significance } & \multicolumn{4}{|c|}{ Critical Values } \\
\hline & & \multicolumn{2}{|c|}{ (a) } & \multicolumn{2}{|c|}{ (b) } \\
\hline & & $\mathrm{I}(0)$ & I(1) & $\mathrm{I}(0)$ & I(1) \\
\hline \multicolumn{6}{|l|}{ F-statistic } \\
\hline \multirow[t]{4}{*}{4.775} & $10 \%$ & 3.47 & 4.45 & 3.408 & 4.473 \\
\hline & $5 \%$ & 4.01 & 5.07 & 3.969 & 5.125 \\
\hline & $2.5 \%$ & 4.52 & 5.62 & - & - \\
\hline & $1 \%$ & 5.17 & 6.36 & 5.193 & 6.526 \\
\hline \multicolumn{6}{|l|}{$t$-statistic } \\
\hline \multirow[t]{4}{*}{-2.327} & $10 \%$ & -3.13 & -3.84 & -3.070 & -3.757 \\
\hline & $5 \%$ & -3.41 & -4.16 & -3.396 & -4.086 \\
\hline & $2.5 \%$ & -3.65 & -4.42 & - & - \\
\hline & $1 \%$ & -3.96 & -4.73 & -3.952 & -4.710 \\
\hline
\end{tabular}

Notes: (a) denotes the critical values proposed by Pesaran et al. [81] and (b) denotes the critical values proposed by Kripfganz and Schneider [91].

The results showed that the value of F-statistic from the ARDL model is inferior to the critical values of Pesaran et al. [82] and Kripfganz and Schneider [92] for the lower bound, I(0), for a 1\% level of significance. Regarding the t-statistic, the absolute calculated value is lower than the critical values 
of the lower bound proposed by the previous authors for all the levels of significance considered. According to the above results, the null hypothesis cannot be rejected, which means that there is no co-integration among the variables. Therefore, it can be concluded that between IPI and the other considered variables are only short-run relationships. The modelling of these relationships is performed using the short-run ARDL model.

\subsection{Econometric Model of the Economic Growth in Romania}

The short-run ARDL model of IPI in relation to the variables INT, R_EXCH and BCI is presented in Table 5.

Table 5. Estimates from the autoregressive distribute lag (ARDL) short-run model.

\begin{tabular}{|c|c|c|c|c|}
\hline Regressor & Coefficient & Std. Error & Characteristics & \\
\hline $\mathrm{D}(\mathrm{IPI}(-1))$ & $-0.375^{* * *}$ & 0.063 & Dependent variable & $\mathrm{D}(\mathrm{IPI})$ \\
\hline $\mathrm{D}(\mathrm{IPI}(-2))$ & $-0.158^{* * *}$ & 0.057 & Structural breaks dummies & Yes \\
\hline $\mathrm{D}(\mathrm{INT})$ & $-0.684^{* *}$ & 0.302 & Information criteria & AIC \\
\hline $\mathrm{D}(\mathrm{INT}(-1))$ & 0.283 & 0.318 & ARDL lag order & $(2,2,1,4)$ \\
\hline $\mathrm{D}(\mathrm{INT}(-2))$ & 0.230 & 0.298 & R-Squared & 0.568 \\
\hline D(R_EXCH) & 0.334 & 1.466 & Adjusted R-Squared & 0.523 \\
\hline $\mathrm{D}\left(\mathrm{R} \_\mathrm{EXCH}(-1)\right)$ & $4.234^{* * *}$ & 1.463 & Log likelihood & -369.951 \\
\hline $\mathrm{D}(\mathrm{BCI})$ & 0.907 & 0.862 & F-statistic & 12.434 \\
\hline $\mathrm{D}(\mathrm{BCI}(-1))$ & $2.855^{* * *}$ & 0.875 & Prob(F-statistic) & 0.000 \\
\hline $\mathrm{D}(\mathrm{BCI}(-2))$ & 1.258 & 0.894 & Ramsey RESET Test & $0.362^{\mathrm{a}}$ \\
\hline $\mathrm{D}(\mathrm{BCI}(-3))$ & 0.714 & 0.862 & $\begin{array}{l}\text { Breusch-Godfrey Serial } \\
\text { Correlation LM }\end{array}$ & $0.269^{a}$ \\
\hline $\mathrm{D}(\mathrm{BCI}(-4))$ & $-2.516^{* * *}$ & 0.858 & Breusch-Pagan-Godfrey & $0.774^{\mathrm{a}}$ \\
\hline $\mathrm{C}$ & 0.383 & 0.255 & $\mathrm{ARCH}$ test & $1.176^{\mathrm{a}}$ \\
\hline @Trend & 0.002 & 0.003 & Jarque-Bera & $7.932^{b}$ \\
\hline
\end{tabular}

Notes: ${ }^{a}$ The null hypothesis is not rejected at the $5 \%$ level of significance. ${ }^{b}$ The null hypothesis is not rejected at the $1 \%$ level of significance. *** and ** denote statistical significance at the $1 \%$ and $5 \%$ level, respectively.

The coefficients of the ARDL short run showed that IPI is significantly and negatively influenced by its own values with 1 and 2 lags. The current values of INT also have a significant and negative influence on the IPI formation, while the lagged values have a positive but not a significant influence. Regarding the relationship between the R_EXCH and IPI, it can be observed that values of IPI are positive and significantly influenced by the previous values of R_EXCH lagged by 1 period. Finally, $\mathrm{BCI}$ has a significant impact on IPI, positive at 1 lag and negative at 4 lags.

According to the Fisher test, the short-run ARDL model in relation to INT, R_EXCH and BCI is statistically significant for a risk of $1 \%$. The value of the determination coefficient indicates that a percentage of $56.8 \%$ from the IPI variation is explained through the ARDL model relative to the monetary policy interest rate, real exchange rate and Euro area Business Climate Indicator.

Model validation is done on the basis of tests concerning the coefficient stability, the correctness of the model and the hypotheses on residuals: normality, no serial correlation and homoscedasticity.

The representations of CUSUM and CUSUM of Squares indicate the coefficients stability, the variation of cumulated residuals and of the squares of cumulated residuals being within the limits of the interval corresponding to the confidence level of 95\% (Figure 4). According to the Ramsey RESET test (Table 5), the null hypothesis is not rejected, therefore the model is correctly specified. Furthermore, all hypotheses on residual are verified, therefore the model is validated. 


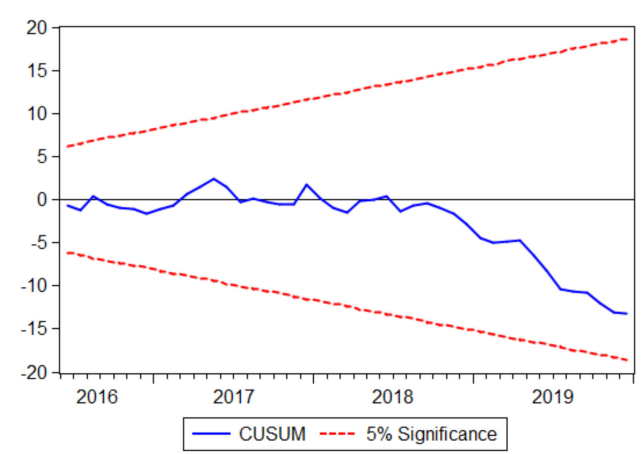

(a)

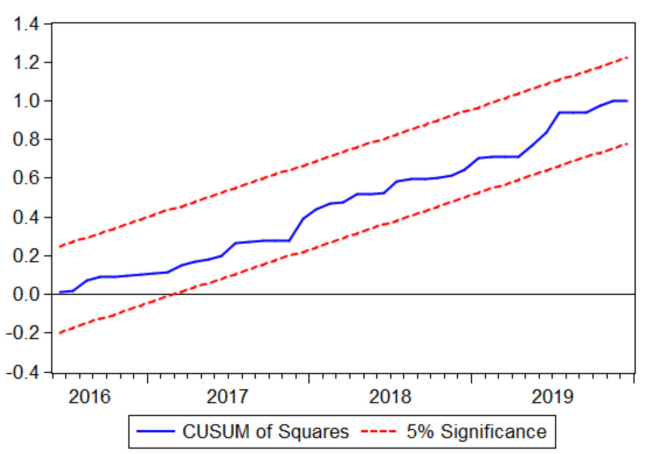

(b)

Figure 4. Plots for the (a) CUSUM and (b) CUSUM of Squares.

\subsection{Robustness of the Cointegration Analysis}

Apart from the ARDL model, we are also interested in the dynamic relationship among the variables. To this end, in this study we generated impulse-response functions (IRFs) based on Vector Autoregressive (VAR) system. IRFs trace out the responsiveness of the dependent variable to the shocks to each of the variables in the system [96]. Figure 5 shows the impulse responses for IPI associated with separate unit shocks to INT, R_EXCH and BCI considering 18 periods.

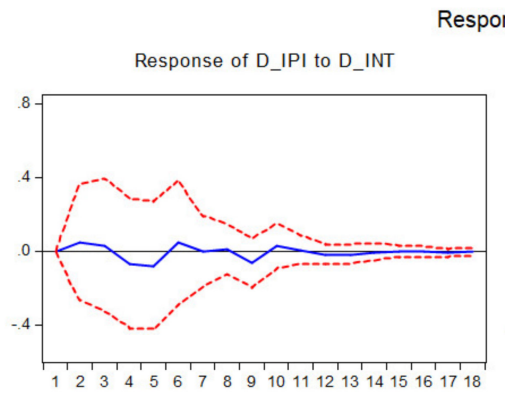

(a)

Response to Cholesky One S.D. (d.f. adjusted) Innovations \pm 2 S.E.

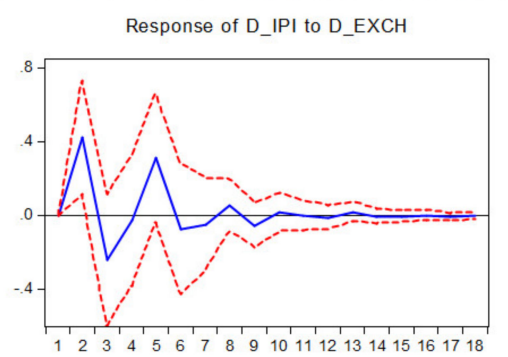

(b)

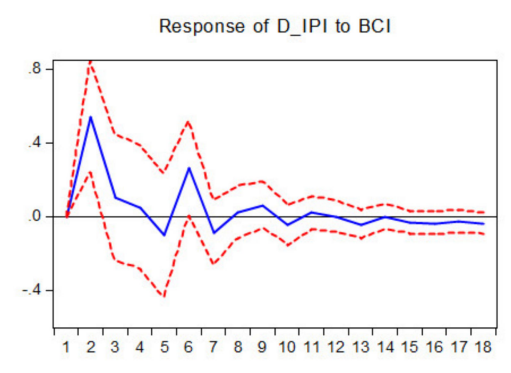

(c)

Figure 5. Impulse responses of D_IPI for innovations in (a) D_INT, (b) D_EXCH and (c) BCI.

The graph of impulse response function showed that INT indicate a positive effect in Periods 1 to 3 and smooth fluctuations in the following periods, reaching a slight effect in the 10th period. When the impulse is R_EXCH, the response of IPI has an obvious fluctuation until the steady state beginning from the 10th period, with the highest positive effect in the 2nd period and a lowest negative effect in the 3rd period. The impulse of BCI determines, also, an obvious fluctuation in the response of IPI. The highest positive effect was registered in the 2 nd period, while the lowest negative effect was reached in Periods 5 and 7 . The results obtained agrees with the ones from the cointegration analysis, revealing that impulses to INT, R_EXCH and BCI generate large fluctuations in the response of IPI in the first 5-6 periods analysed, with smooth fluctuations in the following periods.

To verify the robustness of the results obtained in the previous section, a pairwise Granger causality test is applied (Table 6). 
Table 6. Results of the causality tests.

\begin{tabular}{|c|c|c|c|}
\hline Null Hypothesis & Obs & k & F-statistic \\
\hline INT does not Granger cause IPI ${ }^{\text {a }}$ & \multirow{2}{*}{202} & \multirow{2}{*}{2} & $3.364^{* *}$ \\
\hline IPI does not Granger cause INT $^{a}$ & & & 0.052 \\
\hline R_EXCH does not Granger cause IPI ${ }^{\text {a }}$ & \multirow{2}{*}{202} & \multirow{2}{*}{2} & $3.208^{* *}$ \\
\hline IPI does not Granger cause R_EXCH ${ }^{a}$ & & & 1.190 \\
\hline BCI does not Granger cause IPI ${ }^{b}$ & \multirow{2}{*}{199} & \multirow{2}{*}{5} & $4.939^{* * *}$ \\
\hline IPI does not Granger cause $\mathrm{BCI}{ }^{\mathrm{b}}$ & & & 1.796 \\
\hline R_EXCH does not Granger cause INT a & \multirow{2}{*}{202} & \multirow{2}{*}{2} & 2.054 \\
\hline INT does not Granger cause R_EXCH ${ }^{a}$ & & & 0.012 \\
\hline BCI does not Granger cause INT ${ }^{b}$ & \multirow{2}{*}{198} & \multirow{2}{*}{6} & 0.455 \\
\hline INT does not Granger cause BCI ${ }^{b}$ & & & 0.405 \\
\hline BCI does not Granger cause $\mathrm{R} \_E X C H^{b}$ & \multirow{2}{*}{199} & \multirow{2}{*}{5} & 1.266 \\
\hline R_EXCH does not Granger cause BCI ${ }^{b}$ & & & 1.592 \\
\hline
\end{tabular}

Notes: ***, ${ }^{* *}$ and $*$ denote statistical significance at the $1 \%, 5 \%$ and $10 \%$ level. ${ }^{a}$ Denotes the causalities between variables analysed using the Granger causality test. ${ }^{b}$ Denotes the causalities between variables analysed using the Toda-Yamamoto causality approach.

If both time series are stationary, the causality analysis is performed using the Granger test; but, if the time series have different integration orders, the causality analysis is conducted using the Toda-Yamamoto approach [101]. The causality tests confirm the existence of unidirectional causality, from factors considered in IPI, which means that the monetary policy interest rate, the real exchange rate and the business climate indicator are Granger cause for IPI (Table 6). The causality relationships obtained between the considered variables are shown in Figure 6. The Granger causality tests confirm the cointegration analysis results through the ARDL approach, namely, that INT, R_EXCH and BCI are cause factors for IPI.

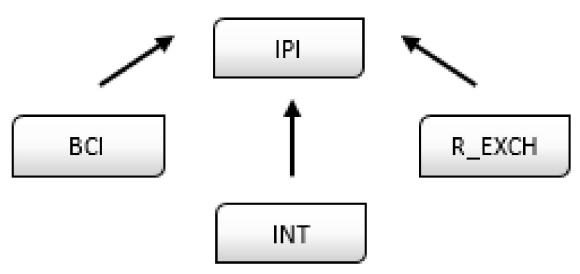

Figure 6. Significant causalities between the Industrial Production Index (IPI) and the considered factors. Source: Authors' schema

\section{Discussions and Conclusions}

The study of economic growth and its determining factors has been the subject of numerous studies, and due to its importance, it is still a highly relevant topic. Economic growth can be influenced by a wide range of factors. In this study, we focused on analysing the impact of the interest rate, the exchange rate and the business climate in the Euro area on the economic growth in Romania, between January 2003 and July 2019, and in the context of the country's accession to the Euro area.

The impact of these factors on the industrial production index was analysed using short-run ARDL models. The main results showed that, in a short run, the two rates have different influences on the economic growth: The interest rate has a negative influence, while the exchange rate has a positive influence. These results are consistent with the results described by economic theory and reported by other empirical analyses.

Our study obtained a reverse relationship between the evolution of interest rate and industrial production, confirming the capacity of this main instrument of monetary policy to stimulate the economic activity in the short run. Interest rate reduction decreases the cost of crediting and stimulates consumption and current supply, encouraging real economy. The risk of inflation rate growth, distortions in the system of relative prices and a growth in the gap between investments and savings 
make the expansionist monetary policy an unviable long-term solution. Cautious handling of interest rates together with coordinated fiscal measures maintain, in the short term, their potential of stimulating economic growth in Romania.

Based on our findings, we can conclude that the hypothesis $H 1$ regarding the influence of the interest rate on the economic growth in Romania is validated.

Economic growth is associated with stability in the exchange rate in developed countries (see, for example, the results of Schnabl's analysis [102] for the countries at EMU periphery). Still, within the developing economies, the exchange rate is often used as an instrument for acquiring comparative advantages by diminishing the prices of exported goods. The acceleration of economic growth tends to be associated with the depreciation of the exchange rate [103]. The stimulation of exports, through currency depreciation, is associated with the growth of industrial production. Thus, the exchange rate positively influences IPI, but this relationship cannot be maintained in the long run due to its negative effects, such as financial instability, inflation and reduction in the money purchasing power. The currency depreciation is associated with the economic growth through other effects as well, alongside export stimulation. The results of our analysis are similar to the results described in the World Bank's analysis [104] and they are supported by the economic theory. Therefore, the positive relationship between the exchange rate and the economic growth is validated in the short-run and, mainly, for the developing countries.

The hypothesis $\mathrm{H} 2$ regarding the influence of the exchange rate on the economic growth in Romania is validated.

The results of our analysis show there is a short-term positive relation between IPI and BCI, with a gap of up to three periods, confirming that the evolution of the business climate in the Euro area generates similar evolution in industrial production in Romania. Positive business climate in the Euro area, reflected by the trust indicators, stimulates the demand for imports and accelerates industrial production in Romania oriented towards export to European market. Considering high dependence of Romanian exports on the evolution of demand on the European market, the positive relation between $\mathrm{BCI}$ and IPI is not at all surprising. Change in the direction of the relationship after four periods may indicate low elasticity of the supply of Romanian producers, which adapt with a delay to changes in the business climate of the Euro area.

The hypothesis H3 regarding the influence of the Business Climate Indicator on the economic growth in Romania is validated.

The literature in the field supports the relationships identified between such variables as (i) $[7,12,18-20]$ the relationship between economic growth and interest rate; (ii) $[31,34,36]$ the relationship between economic growth and exchange rate; and (iii) [50,52-54] the relationship between economic growth and business climate in the Euro area.

In the empirical study, we considered that the identification of structural breaks is important in order to obtain a proper cointegration analysis. So, the identified structural breaks in the evolution of IPI explained the instability of initially calculated ARDL model coefficients. Introduction into the model of dummy variables corresponding to structural breaks served to stabilize and validate the model. The structural breaks 2008M10, 2013M03 and 2016M04 moments are explained by the economic context of Romania.

According to National Forecast Commission [105], the analysis of industrial production indices shows that the highest level was reached in October 2008. This is the moment when the evident and accelerated decline of industrial production began, the following three months recording significant contractions of industrial production, from a decrease of 3\% in October 2008 to 18\% in December 2008, compared to the same months of the previous year. The decrease of industrial production in Romania occurred in the context of high dependence on the demand on the international market, which had been significantly reduced by the global economic crisis. 
In April 2013, industrial production had the highest growth in the EU, which was attributed to growth in the processing industry [106] of $21.9 \%$ and $12.3 \%$ in the extractive industry [107]. Revival of foreign demand and the launch of new car models by main car producers in Romania are viewed as main determinants of this boost in industrial production.

In the following month, May 2013, industrial production dropped compared to April by $10.7 \%$, [107] being the lowest annual decrease since October 2008. The decrease of industrial production was also the most sudden in the EU, where the decrease on adjusted series amounted to $0.6 \%$ compared to the previous month, and to $0.3 \%$ compared to the euro area [108]. According to NBR [106], this volatility was mainly due to windfall effect generated by extension of holiday' days and reschedule the delivery of orders to April.

In April 2016, industrial production grew by 3.5\% compared to the previous month due to the increase of production and delivery of electrical power and heat, gas, heated water and conditioned air $(5.9 \%)$, and an increase in the processing industry (3.2\%) [109]. The increase was much higher compared to the average of $1.3 \%$ in the EU28. According to NBR [106], increase in the consumption of electrical power and higher efficiency of the processing industry are the main factors that contributed to increasing the growth pace of industrial production. In May 2016, the trend was reversed, the industrial production decreasing by $4.0 \%$ compared to the previous month, being the fourth largest industry in the EU [110] due to decrease in all industrial sectors. [111]. This evolution has been attributed to loss of pace in the processing industry and a deepening of the contraction in the extractive industry, as well as problems related to competitiveness in the textile industry and a slight slow-down in construction [106].

The analysis may be extended to more determinants of growth and also could comprise other states in Central and Eastern Europe to measure the capacity of economic policies to stimulate economic activity, in the context of growth of global interdependencies. The implication of our results should be considered from the perspective of the monetary policy that could use the interest rate and the exchange rate to support economic growth, in the context of a higher dependence between the internal economic environment and the external (European) one.

Author Contributions: All authors contributed equally to the research presented in this paper and to the preparation of the final manuscript. All authors have read and agreed to the published version of the manuscript.

Funding: This research received no external funding.

Conflicts of Interest: The authors declare no conflict of interest.

\section{References}

1. Barsky, R.B.; Sims, E.R. Information, Animal Spirits, and the Meaning of Innovations in Consumer Confidence. Am. Econ. Rev. 2012, 102, 1343-1377. [CrossRef]

2. Barro, R.J.; Sala-i-Martin, X. Economic Growth and Convergence across the United States. NBER Work. Pap. 1990, 3419. [CrossRef]

3. Harvey, C.R. The real term structure and consumption growth. J. Financ. Econ. 1988, 22, 305-333. [CrossRef]

4. Hossain, A.A. Inflation volatility, economic growth and monetary policy in Bangladesh. Appl. Econ. 2015, 47, 5667-5688. [CrossRef]

5. Low, Y.W.; Chan, T.-H. Foreign Exchange Rate, Interest Rate, Inflation Rate and Economic Growth in Malaysia. Glob. Bus. Manag. Res. Int. J. 2017, 9, 110-127.

6. Abdelkafi, I. The Relationship Between Public Debt, Economic Growth, and Monetary Policy: Empirical Evidence from Tunisia. J. Knowl. Econ. 2018, 9, 1154-1167. [CrossRef]

7. Ozer, M.; Karagol, V. Relative effectiveness of monetary and fiscal policies on output growth in Turkey: An ARDL bounds test approach. Q. J. Econ. Econ. Policy 2018, 13, 391-409. [CrossRef]

8. Próchniak, M.; Witkowski, B. Real economic convergence and the impact of monetary policy on economic growth of the EU countries: The Analysis of Time Stability and the Identification of Major Turning Points Based on the Bayesian Methods. Natl. Bank Pol. Work. Pap. 2012, 137, 1-75. [CrossRef] 
9. Mallick, S.; Sousa, R. Real Effects of Monetary Policy in Large Emerging Economies. Macroecon. Dyn. 2012, 16, 190-212. [CrossRef]

10. Murgia, L. The effect of monetary policy shocks on macroeconomic variables: Evidence from the Eurozone. In Economics Letters; Elsevier: Amsterdam, The Netherlands, 2020; Volume 186. [CrossRef]

11. Warman, F.; Thirlwall, A.P. Interest rates, saving, investment and growth in Mexico 1960-90: Tests of the financial liberalisation hypothesis. J. Dev. Stud. 1994, 30, 629-649. [CrossRef]

12. Ganev, G.; Molnar, K.; Rybiñski, K.; Przemyslaw, W. Transmission Mechanism of Monetary Policy in Central and Eastern Europe, CASE-Center for Social and Economic Research, Warsaw. Available online: https://www.case-research.eu/files/?id_plik=3922 (accessed on 7 March 2020).

13. Dornbusch, R. Expectations and Exchange Rate Dynamics. J. Political Econ. 1976, 84, 1161-1176. [CrossRef]

14. Balassa, B. The purchasing power parity doctrine: A reappraisal. J. Political Econ. 1964, 72, 584-596. [CrossRef]

15. Samuelson, P. Theoretical notes on trade problems. Rev. Econ. Stat. 1964, 46, 145-154. [CrossRef]

16. Houthakker, H.; Magee, S. Income and Price Elasticities in World Trade. Rev. Econ. Stat. 1969, 51, 111-125. [CrossRef]

17. Krugman, P. Differences in income elasticities and trends in real exchange rates. Eur. Econ. Rev. 1989, 33, 1031-1046. [CrossRef]

18. Franke, G. Exchange rate volatility and international trading strategy. J. Int. Money Financ. 1991, 10, $292-307$. [CrossRef]

19. Frankel, J.A.; Romer, D. Does Trade Cause Growth? Am. Econ. Rev. 1999, 89, 379-399. [CrossRef]

20. Rose, A.K. One Money, One Market: The Effect of Common Currencies on Trade. EconPol 2000, 15, 7-45. [CrossRef]

21. Lee, K.S.; Werner, R.A. Reconsidering Monetary Policy: An Empirical Examination of the Relationship between Interest Rates and Nominal GDP Growth in the U.S., U.K., Germany and Japan. Ecol. Econ. 2018, 146, 26-34. [CrossRef]

22. Organisation for Economic Co-Operation and Development. The Sources of Economic Growth in OECD Countries. Available online: https://www.oecd-ilibrary.org/economics/the-sources-of-economic-growth-inoecd-countries_9789264199460-en (accessed on 18 November 2019).

23. Irwin, D.A.; Terviö, M. Does trade raise income? Evidence from the twentieth century. J. Int. Econ. 2002, 58, 1-18. [CrossRef]

24. Nicita, A. Exchange Rates, International Trade and Trade Policies. Policy Issues in International Trade and Commodities study Series No. 56, United Nations Conference on Trade and Development. Available online: https://unctad.org/en/PublicationsLibrary/itcdtab57_en.pdf (accessed on 27 November 2019).

25. Leigh, D.; Lian, W.; Poplawski-Ribeiro, M.; Szymanski, R.; Tsyrennikov, V.; Yang, H. Exchange Rates and Trade: A Disconnect? IMF Working Paper. 17. Available online: http://www.imf.org/external/pubs/cat/longres. aspx?sk=44746 (accessed on 29 November 2019).

26. Iamsiraroj, S. The foreign direct investment-economic growth nexus. Int. Rev. Econ. Financ. 2016, 42, 116-133. [CrossRef]

27. Borensztein, E.; De Gregorio, E.; Lee, J.-W. How does foreign direct investment affect economic growth? J. Int. Econ. 1988, 45, 115-135. [CrossRef]

28. Sipos, C.; Boleanțu, M. An econometric model for analyzing the impact of exchange rate fluctuations on Romanian economic growth, in the opening of the fourth international conference. Econ. Transform. Manag. 2008. Available online: https://www.researchgate.net/publication/232814946_AN_ECONOMETRIC_ MODEL_FOR_ANALYZING_THE_IMPACT_OF_EXCHANGE_RATE_FLUCTUATIONS_ON_ ROMANIAN_ECONOMIC_GROWTH (accessed on 12 November 2019).

29. Anaripour, J.A. Study on Relationship between Interest Rate and Economic Growth by Eviews (2004-2010, Iran). J. Basic Appl. Sci. Res. 2011, 1, 2346-2352. Available online: https://www.textroad.com/pdf/JBASR/J. \%20Basic.\%20Appl.\%20Sci.\%20Res.,\%201(11)2346-2352,\%202011.pdf (accessed on 20 December 2019).

30. Rodrik, D. The Real Exchange Rate and Economic Growth. Brook. Pap. Econ. Act. 2008, 39, 365-439. Available online: https://www.brookings.edu/wp-content/uploads/2008/09/2008b_bpea_rodrik.pdf (accessed on 22 December 2019). [CrossRef]

31. Razmi, A.; Rapetti, M.; Skott, P. The real exchange rate and economic development. Struct. Chang. Econ. Dyn. 2012, 23, 151-169. [CrossRef] 
32. Ribeiro, R.S.; McCombie, J.; Lima, G.T. Does real exchange rate undervaluation really promote economic growth? Struct. Chang. Econ. Dyn. 2019. [CrossRef]

33. Wesseh, P.K.; Lin, B. Exchange rate fluctuations, oil price shocks and economic growth in a small net-importing economy. Energy 2018, 151, 402-407. [CrossRef]

34. Habib, M.M.; Mileva, E.; Stracca, L. The real exchange rate and economic growth: Revisiting the case using external instruments. J. Int. Money Financ. 2017, 73, 386-398. [CrossRef]

35. Eichengreen, B. The Real Exchange Rate and Economic Growth. Soc. Econ. Stud. 2007, 56, 7-20. Available online: www.jstor.org/stable/27866525 (accessed on 19 December 2019).

36. Ihnatov, I.; Căpraru, B. Exchange Rate Regimes and Economic Growth in Central and Eastern European Countries. Procedia Econ. Financ. 2012, 3, 18-23. [CrossRef]

37. Oliveira, C.A. Investment and Exchange Rate Uncertainty under Different Regimes. Estud. Econ. 2014, 44, 553-577. [CrossRef]

38. Sharifi-Renani, H.; Mirfatah, M. The Impact of Exchange Rate Volatility on Foreign Direct Investment in Iran. Procedia Econ. Financ. 2012, 1, 365-373. [CrossRef]

39. Froot, K.A.; Stein, J.K. Exchange Rates and Foreign Direct Investment: An Imperfect Capital Markets Approach. Q. J. Econ. 1991, 106, 1191-1217. [CrossRef]

40. Grosse, R.; Trevino, L. Foreign Direct Investment in the United States: An Analysis by Country of Origin. J. Int. Bus. Stud. 1996, 27, 139-155. [CrossRef]

41. Klein, M.W.; Rosengren, E. The real exchange rate and foreign direct investment in the United States. Relative wealth vs. relative wage effects. J. Int. Econ. 1994, 36, 373-389. [CrossRef]

42. Takagi, S.; Shi, Z. Exchange rate movements and foreign direct investment (FDI): Japanese investment in Asia, 1987-2008. Jpn. World Econ. 2011, 23, 265-272. [CrossRef]

43. European Commission. The Joint Harmonised EU Programme of Business and Consumer Surveys. User Guide. Available online: https://ec.europa.eu/info/sites/info/files/bcs_user_guide_en_0.pdf (accessed on 4 January 2020).

44. Rua, A.; Composite Indicators for the Euro Area Economic Activity. Economic Bulletin and Financial Stability Report Articles and Banco de Portugal Economic Studies. Available online: https://www.bportugal.pt/sites/ default/files/anexos/papers/ab200207_e.pdf (accessed on 4 January 2020).

45. Strigel, W.H. Business Cycle Surveys: A New Quality in Economic Statistics. Analysing Modern Business Cycles. In Essays Honoring Geoffrey H. Moore; Klein, P.A., Ed.; M. E. Sharpe, Inc.: Armonk, NY, USA, 1990; pp. 69-84.

46. Gelper, S.; Croux, C. On the Construction of the European Economic Sentiment Indicator. Oxf. Bull. Econ. Stat. 2010, 72, 47-62. [CrossRef]

47. Santero, T.; Werterlund, T. Confidence Indicators and Their Relationship to Changes in Economic Activity. OECD Econ. Dep. Work. Pap. 1996, 170. [CrossRef]

48. Mourougane, A.; Roma, M. Can Confidence Indicator be Useful to Predict Short Term Real GDP Growth? Eur. Cent. Bank Work. Pap. 2002, 133, 1-49. Available online: https://www.ecb.europa.eu//pub/pdf/scpwps/ ecbwp133.pdf (accessed on 4 January 2020). [CrossRef]

49. Hansson, J.; Jansson, P.; Löf, M. Business survey data: Do they help in forecasting GDP growth? Int. J. Forecast. 2005, 21, 377-389. [CrossRef]

50. Demirel, S.K.; Artan, S. The Causality Relationships between Economic Confidence and Fundamental Macroeconomic Indicators: Empirical Evidence from Selected European Union Countries. Int. J. Econ. Financ. Issues 2017, 7, 417-424. Available online: https://www.econjournals.com/index.php/ijefi/article/download/ 5356/pdf (accessed on 4 January 2020).

51. Knack, S.; Keefer, P. Does Social Capital Have an Economic Payoff? Across-Country Investigation. Q. J. Econ. 1997, 112, 1251-1288. Available online: www.jstor.org/stable/2951271 (accessed on 9 January 2020). [CrossRef]

52. Gennaioli, N.; Ma, Y.; Shleifer, A. Expectations and Investment. NBER Work. Pap. 2015, 21260. [CrossRef]

53. Das, R.; Das, U. Interrelationships among Growth, Confidence and Governance in the Globalized World-An experiment of some selected countries. Int. J. Financ. Bank. Stud. 2014, 3, 68-83. [CrossRef]

54. Alves, J.C.R. Confidence Indicators and Economic Cycles in Euro Area and Portugal. Master's Thesis, Universidade do Porto, Porto, Portugal, 2019. Available online: https://repositorio-aberto.up.pt/bitstream/ 10216/123761/2/364674.pdf (accessed on 10 March 2020). 
55. Zanin, L. The relationship between changes in the Economic Sentiment Indicator and real GDP growth: A time-varying coefficient approach. Econ. Bull. 2010, 30, 837-846. Available online: http://www.accessecon. com/Pubs/EB/2010/Volume30/EB-10-V30-I1-P78.pdf (accessed on 9 January 2020).

56. De Jongh, J.; Mncayi, P. An econometric analysis on the impact of business confidence and investment on economic growth in post-apartheid South Africa. Int. J. Econ. Financ. Stud. 2018, 10, 115-133. Available online: http://www.sobiad.org/ejournals/journal_IJEF/archieves/ijef_2018_1_ek/j-d-jongh.pdf (accessed on 9 January 2020).

57. National Institute of Statistics. Methodological Specifications for IPI. Available online: http://www.insse.ro/ cms/files/statistici/comunicate/ipi/a15/Precizari\%20metodologice_IPI.pdf (accessed on 1 March 2020).

58. National Institute of Statistics. Press release regarding the provisional GDP data for 2016. Available online: www.insse.ro (accessed on 14 November 2019).

59. Anghel, M.G.; Carp, A.; Bunea, M.; Mirea, M. Model of structural analysis of GDP by resources, uses and property. In Romanian: Model de analiză structurală a PIB după resurse, utilizări și proprietate. Rom. J. Stat. 2018, 7, 21-32. Available online: https://insse.ro/cms/sites/default/files/field/publicatii/revista_romana_ statistica_supliment_07_2018.pdf (accessed on 12 November 2019).

60. National Bank of Romania. Monetary Policy and Standing Facilities Interest Rates. Available online: https://www.bnr.ro/Monetary-Policy--3318.aspx (accessed on 7 March 2020).

61. Pelinescu, E. Economic competitivity and the exchange rate in Romania. In Romanian: Competitivitatea economica si cursul de schimb in România. Inst. Econ. Forecast. 2004, 1, 1-12. Available online: http://www.ipe.ro/RePEc/WorkingPapers/cs5-2004-1.pdf (accessed on 13 November 2019).

62. Gagea, M. Modelling the Confidence in Industry in Romania and other European Member Countries Using the Ordered Logit Model. J. Econ. Forecast. 2014, 17, 15-34. Available online: http://www.ipe.ro/rjef/rjef1_14/ rjef1_2014p15-34.pdf (accessed on 9 January 2020).

63. Chirwa, T.G.; Odhiambo, N.M. The nexus between key macroeconomic determinants and economic growth in Zambia: A dynamic multivariate Granger causality linkage. Empir. Econ. 2019, 57, 301-327. [CrossRef]

64. Dickey, D.; Fuller, W.A. Distribution of the estimates for autoregressive time series with a unit root. J. Am. Stat. Assoc. 1979, 74, 427-431. [CrossRef]

65. Phillips, P.C.B.; Perron, P. Testing for a unit root in time series regression. Biometrika 1988, 75, 335-346. [CrossRef]

66. Phillips, P.; Schmidt, P.; Shin, Y. Testing the null hypothesis of stationarity against the alternative of a unit root: How sure are we that the economic time series have a unit root? J. Econom. 1992, 54, 159-178. [CrossRef]

67. Elliot, G.; Stock, J.H.; Rothenberg, T.J. Efficient tests for an autoregressive unit root. Econometrica 1996, 64, 813-836. [CrossRef]

68. Perron, P. The great crash, the oil price stock, and the unit root hypothesis. Econom. J. Econom. Soc. 1989, 57, 1361-1401. [CrossRef]

69. Zivot, E.; Andrews, D. Further evidence of great crash, the oil price shock and unit root hypothesis. J. Bus. Econ. Stat. 1992, 10, 251-270. [CrossRef]

70. Lumsdaine, R.L.; Papell, D.H. Multiple Trend Breaks and the Unit-Root Hypothesis. Rev. Econ. Stat. 1997, 79, 212-218. [CrossRef]

71. Lee, J.; Strazicich, M.C. Minimum Lagrange Multiplier Unit Root Test with Two Structural Breaks. Rev. Econ. Stat. 2003, 85, 1082-1089. [CrossRef]

72. Carrion-i-Silvestre, J.; Kim, D.; Perron, P. GLS-Based Unit Root Tests with Multiple Structural Breaks under Both the Null and the Alternative Hypotheses. Econom. Theory 2009, 25, 1754-1792. Available online: Jstor.org/stable/40388611 (accessed on 5 March 2020).

73. Ng, S.; Perron, P. LAG Length Selection and the Construction of Unit Root Tests with Good Size and Power. Econometrica 2001, 69, 1519-1544. [CrossRef]

74. Pellini, E. Essays on European Electricity Market Integration, Surrey Energy Economics Centre (SEEC) School of Economics Faculty of Business, Economics and Law University of Surrey 2014. Available online: https://www.seec.surrey.ac.uk/wp-content/uploads/2018/10/2014ElisabettaPelliniThesis.pdf (accessed on 5 March 2020).

75. Perron, P.; Yabu, T. Testing for Shifts in Trend with an Integrated or Stationary Noise Component. J. Bus. Econ. Stat. 2009, 27, 369-396. [CrossRef] 
76. Bajo-Rubio, O.; Díaz-Roldán, C.; Esteve, V. Sustainability of external imbalances in the OECD countries. Appl. Econ. 2011, 46, 1-18. Available online: https://www.researchgate.net/publication/239806717_ Sustainability_of_External_Imbalances_in_the_OECD_Countries (accessed on 6 March 2020). [CrossRef]

77. Andrews, D.W.K.; Ploberger, W. Optimal tests when a nuisance parameter is present only under the alternative. Econometrica 1994, 62, 1383-1414. [CrossRef]

78. Phillips, P.C.B. Time series regression with unit roots. Econometrica 1987, 55, 277-302. Available online: https://www.jstor.org/stable/1913237?seq=1 (accessed on 1 March 2020). [CrossRef]

79. Sargan, J.D.; Bhargava, A. Testing residuals from least squares regression for being generated by the gaussian random walk. Econometrica 1983, 51, 153-174. [CrossRef]

80. Carrion-i-Silvestre, J. Gauss code GLS-based Unit Root Tests with Multiple Structural Breaks Both Under the Null and the Alternative Hypotheses. Available online: http://people.bu.edu/perron/code.html (accessed on 2 March 2020).

81. Pesaran, M.H.; Shin, Y. An autoregressive distributed-lag modelling approach to cointegration analysis. Econom. Soc. Monogr. 1998, 31, 371-413. Available online: http://citeseerx.ist.psu.edu/viewdoc/download? doi=10.1.1.153.3246\&rep=rep1\&type=pdf (accessed on 25 November 2019).

82. Pesaran, M.H.; Shin, Y.; Smith, R.J. Bounds testing approaches to the analysis of level relationships. J. Appl. Econom. 2001, 16. [CrossRef]

83. Engle, R.; Granger, C.W.J. Co-integration and error correction: Representation, estimation, and testing. Econometrica 1987, 55, 251-276. [CrossRef]

84. Johansen, S.; Juselius, K. Maximum likelihood estimation and inference on cointegration-With applications to the demand for money. Oxf. Bull. Econ. Stat. 1990, 52, 169-210. [CrossRef]

85. Kanjilal, K.; Ghosh, S. Income and price elasticity of gold import demand in India: Empirical evidence from threshold and ARDL bounds test cointegration. Resour. Policy 2014, 41, 135-142. [CrossRef]

86. Banerjee, A.; Dolado, J.J.; Galbraith, J.W.; Hendry, D. Co-integration, error correction, and the econometric analysis of non-stationary data. OUP Cat. 1993. [CrossRef]

87. Narayan, P.K. The saving and investment nexus for China: Evidence from cointegration tests. Appl. Econ. 2015, 37, 1979-1990. [CrossRef]

88. Garza-Rodriguez, J. Tourism and Poverty Reduction in Mexico: An ARDL Cointegration Approach. Sustainability 2019, 11, 845. [CrossRef]

89. Wen, X.; Quacoe, D.; Quacoe, D.; Appiah, K.; Danso, B.A. Analysis on Bioeconomy's Contribution to GDP: Evidence from Japan. Sustainability 2019, 11, 712. [CrossRef]

90. Arize, A.; Kalu, E.U.; Nkwor, N.N. Banks versus markets: Do they compete, complement or Co-evolve in the Nigerian financial system? An ARDL approach. Res. Int. Bus. Financ. 2018, 54, 427-434. [CrossRef]

91. Alsamara, M.; Mrabet, Z.; Jarallah, S.; Barkat, K. The switching impact of financial stability and economic growth in Qatar: Evidence from an oil-rich country. Q. Rev. Econ. Finnanc. 2018, 73, 2015-2216. [CrossRef]

92. Kripfganz, S.; Schneider, D.C. Response Surface Regressions for Critical Value Bounds and Approximate P-Values in Equilibrium Correction Models. Manuscript. University of Exeter and Max Planck Institute for Demographic Research 2018. Available online: www.kripfganz.de (accessed on 5 March 2020).

93. Brown, R.L.; Durin, J.; Evans, J.M. Techniques for Testing the Constancy of Regression Relationships over Time. J. R. Stat. Soc. 1975, 37, 149-192. [CrossRef]

94. Pesaran, M.H.; Pesaran, B. Working with Microfit 4.0: Interactive Econometric Analysis; Oxford University Press: Oxford, UK, 1997.

95. Ramsey, J.B. Tests for Specification Errors in Classical Linear Least-Squares Regression Analysis. J. R. Stat. Soc. B 1969, 31, 350-371. [CrossRef]

96. Brooks, C. Introductory Econometrics for Finance, 3rd ed.; Cambridge University Press: New York, NY, USA, 2008.

97. Gujarati, D.N.; Porter, D.C. Basic Econometrics, 5th ed.; MCGraw-Hill Irwin: New York, NY, USA, 2008.

98. Wooldridge, J.M. Introductory Econometrics. In A Modern Approach, 6th ed.; Cengage Learning: Boston, MA, USA, 2016.

99. Milea, C. Exchange Rate Evolution in Romania-Effects on the Financial-Monetary Market. Financ. Stud. 2016, 20, 17-36. Available online: http://fs.icfm.ro/vol20i4p17-36.pdf (accessed on 14 January 2020).

100. Č́žžek, P.; Härdle, W.; Weron, R. Statistical Tools in Finance and Insurance; Springer: Berlin/Heidelberg, Germany; New York, NY, USA, 2005. 
101. Toda, H.Y.; Yamamoto, T. Statistical inference in vector autoregressions with possibly integrated processes. J. Econ. 1995, 66, 225-250. [CrossRef]

102. Schnabl, G. Exchange rate volatility and growth in small open economies at the EMU periphery. Econ. Syst. 2008, 32, 70-91. [CrossRef]

103. Hausmann, R.; Pritchett, L.; Rodrik, D. Growth Accelerations. J. GreEcon 2005, 10, 303-329. [CrossRef]

104. Haddad, M.; Pancaro, C. Can Real Exchange Rate Undervaluation Boost Exports and Growth in Developing Countries? Yes, But Not for Long. World Bank Econ. Premise 2010, 20, 1-5. Available online: http: //siteresources.worldbank.org/INTPREMNET/Resources/EP20.pdf (accessed on 26 January 2020).

105. Comisia Națională de Prognoză/National Commission for Forecasting. Romanian Industry in Post-Crisis Period. In Romanian: Industria Românească în Perioada de Criză. Available online: http://www.cnp.ro/user/ repository/industria_romaneasca_in_perioada_de_criza.pdf (accessed on 4 March 2020).

106. National Bank of Romania (NBR). Monthly Bulletin. Available online: https://www.bnr.ro/Regularpublications-2504.aspx (accessed on 4 March 2020).

107. Institutul Național de Statistică/National Institute of Statistics. Indicii Producţiei Industriale (Indices of Industrial Production). Press release, 144; 11 June 2013. Available online: http://www.insse.ro/cms/ro/ content/indicele-productiei-industriale (accessed on 3 March 2020).

108. European Comission. May 2013 compared with April 2013 Industrial production down by $0.3 \%$ in euro area Down by $0.6 \%$ in EU27, Press Corner. 12 July 2013. Available online: https:/ec.europa.eu/commission/ presscorner/detail/en/STAT_13_106 (accessed on 4 March 2020).

109. Institutul Național de Statistică/National Institute of Statistics. Indicii Producţiei Industriale (Indices of Industrial Production). Press release, 152; 14 June 2016. Available online: http://www.insse.ro/cms/sites/ default/files/com_presa/com_pdf/ipi04r16.pdf (accessed on 3 March 2020).

110. Eurostat. News Release Euroindicators. 13 July 2016. Available online: https://ec.europa.eu/eurostat/ documents/2995521/7559641/4-13072016-AP-EN.pdf/d75a7aea-786c-479c-af85-8867ee93201d (accessed on 3 March 2020).

111. Institutul Național de Statistică/National Institute of Statistics. Indicii Producţiei Industriale (Indices of Industrial Production). Press release, 182; 13 July 2016. Available online: http://www.insse.ro/cms/sites/ default/files/com_presa/com_pdf/ipi05r16.pdf (accessed on 3 March 2020).

(C) 2020 by the authors. Licensee MDPI, Basel, Switzerland. This article is an open access article distributed under the terms and conditions of the Creative Commons Attribution (CC BY) license (http://creativecommons.org/licenses/by/4.0/). 